\title{
The Impact of Psychological Factors and Religious Adherence on Household's Dealing with Poverty-Driven Vulnerability Situation: A Critical Discourse on Kelantan and Terengganu
}

\author{
Senadjki Abdelhak ${ }^{1}$, Jamalludin Sulaiman ${ }^{1} \&$ Saidatulakmal Mohd ${ }^{1}$ \\ ${ }^{1}$ School of Social Sciences, Universiti Sains Malaysia, Penang, Malaysia \\ Correspondence: Senadjki Abdelhak, School of Social Sciences, Economic Section, Universiti Sains Malaysia \\ USM, 11800, Pulau Pinang, Malaysia. Tel: 60-12-429-0450. E-mail: absenadjki@gmail.com
}

Received: May 13, 2012 Accepted: June 25, 2012 Online Published: September 20, 2012

doi:10.5539/ass.v8n12p192

URL: http://dx.doi.org/10.5539/ass.v8n12p192

\begin{abstract}
It is documented that in the households' experience of vulnerability to poverty, religious and psychological factors have been inextricably but indirectly linked. These factors, according to researchers' findings, have played a decisive role in enhancing households' coping capacity in an attempt to ease their vulnerabilities. The same factors however could also have adverse effects on household in their vulnerability to poverty as they may weaken people's risk-management and coping strategies. This study will attempt to extend the discussion of this issue by an investigation of psychological and religious impact on households' risk management and coping strategies. In order to understand the dynamics of interrelations between these factors, a study was done in the states of Kelantan and Terengganu in Malaysia. Using a structured socio-economic questionnaire, 302 randomly selected farmers from both the states were tested. The results showed that distress, depression and feeling discouraged dramatically reducing farmers' monthly income. Also the results indicated that the more the religious farmers are the highest their monthly income is. Instead of being motivated when experiencing stressors, farmers behaved negatively. This was confirmed as the results appointed the existence of a significant and negative relationship between farmers' psychological situation and their coping strategies. At the same time religious farmers implemented only fewer strategies. But these strategies found to be effective and efficient as their monthly income is higher compared to those who seldom practice religious commitments.
\end{abstract}

Keyword: poverty, farmers, psychology, religion, coping strategies, risk-management strategies, Kelantan and Terengganu

\section{Introduction}

Poverty is one of the serious social problems that challenge the security and stabilisation of societies. All communities, regardless of the degree of their economic fortunes and development, suffer from this phenomenon and its adverse effects both at the family and community level. Not only does Poverty affect individuals' material and physical needs, but it has also been an underlying cause of psychological problems and moral decay. Studies have shown that poverty had contributed to mental illness (Patel \& Kleinman, 2003; Riskind, 1999).The high poverty rate had led to some forms of mental sufferings such as depression, anxiety, schizophrenia, and addiction (Booth \& Lloyd, 2000; Page \& Fragar, 2002; Eisner et al., 1998). At the same time, the psychological problems also have a significant impact on individual's welfare and that therefore the person experiencing mental problems does not possess sufficient capacity to make the right decisions to sustain his family survivals.

Households, particularly farmers, are prone to several risks and shocks. With the lack of access to assets and entitlements, households find it difficult to cope with and manage against these stressors. Households have applied a variety of strategies to deal with negative events in their lives. Yet, in many cases these strategies have failed to shield their economic and social conditions (Ersado, 2006; Wamsler, 2007). Therefore, households' strategies are important elements that determine the level of their poverty. The effectiveness of risk management and coping strategies to insulate households from stressors is determined by many factors: severity and frequency of the shocks or negative event (Kamur \& Routray, 2009); Economic condition (Eriksen \& Silva, 2009); households' psychological situation (McCubbin \& figley, 1983; Chaudhuri, 2003; Garnefski et al, 2005; Beedell \& Rehman, 1999; Goudge et al., 2007; Berry et al., 2009; Hinton and Earnest, 2010) and religious adherence (Ensor, 2003; 
Chester et al., 2008; Gaillard \& Texier, 2010; Levin, 1994, Mitchell, 2003; Albernethy et al, 2003; Andreana, 2010; crawfold, 1998; and keonig, 2007).

The issue of poverty among farmers has been documented well with the application of various theories and models. Many variables and factors like assets, political situation and agricultural policies, economic condition and households characteristics were all recognised as the main sources of poverty, although the fact that a suite of psychological and socio-cultural variables also significantly impact farmers' decision-making and behaviours is simply overlooked by agricultural economists (Edwards-Jones et al., 1998, p.154). While poverty is commonly understood as a lack of economic resources; poverty reduction efforts would be ineffective unless the concept of poverty embedded in the social-cultural political, economic and psychological contexts (Mohanthy and Misra, 2000). In this perspective, Carr et al (2008) argue that a thoughtful articulation of what Organizational Psychology uniquely stands for, and can offer, is therefore needed. Religion meanwhile has been playing decisive role to draw viable decision and strategies (Levin, 1994, Mitchell, 2003; Gillard \& Paton, 1999).

This study will attempt to extend the discussion of this issue by an investigation of psychological and religious impact on households' risk management and coping strategies. In order to understand the dynamics of interrelations between these factors, the study was undertaken in the states of Kelantan and Terengganu in Malaysia with the objective to answer the following questions: (i) How do psychological factors and the religious adherence affect household's responses to risks and shocks? And, (2) Do these factors lead households to fall in poverty traps?

\section{The Theoretical Framework}

Farmers have long been associating with a huge range of factors that affect their farming activities such as biophysical events, economic conditions and agricultural reform policies. However, farmers' characteristics and behaviours are also important elements that determine the effectiveness of their farming strategies and therefore their families' subsistence.

The effectiveness of farmers' strategies, mainly coping/dealing with their potential uncertainties, plays an influential role in determining the degree of their poverty. People behave and handle risks differently. Households adopt a variety of strategies to deal with disastrous events. These strategies can be categorised into two sets: ex-post strategies (or coping strategies) and ex-ante strategies (or risk-management strategies) ${ }^{1}$. Some households are more competent, and others are less competent and in some cases their interventions leave them in poverty trap. It is well recognised that farming is the most industry leading to high rates of injury, illness, disability and death, mental health, high rates of stress, depression, and high rates of suicide (CRMH, 2005). These factors have a significant effect on the farmers' decision-making. Farmers develop the above threats by them experiencing negative events and stressors such as natural disasters (Berry et al., 2011, Yeung \& Chan, 2007) and financial difficulties (Gorgievski et al., 2010). Poverty also found to be the main source leading to psychological problems (Kahn et al., 2000; Goudge et al, 2007; and Berry et al., 2009).

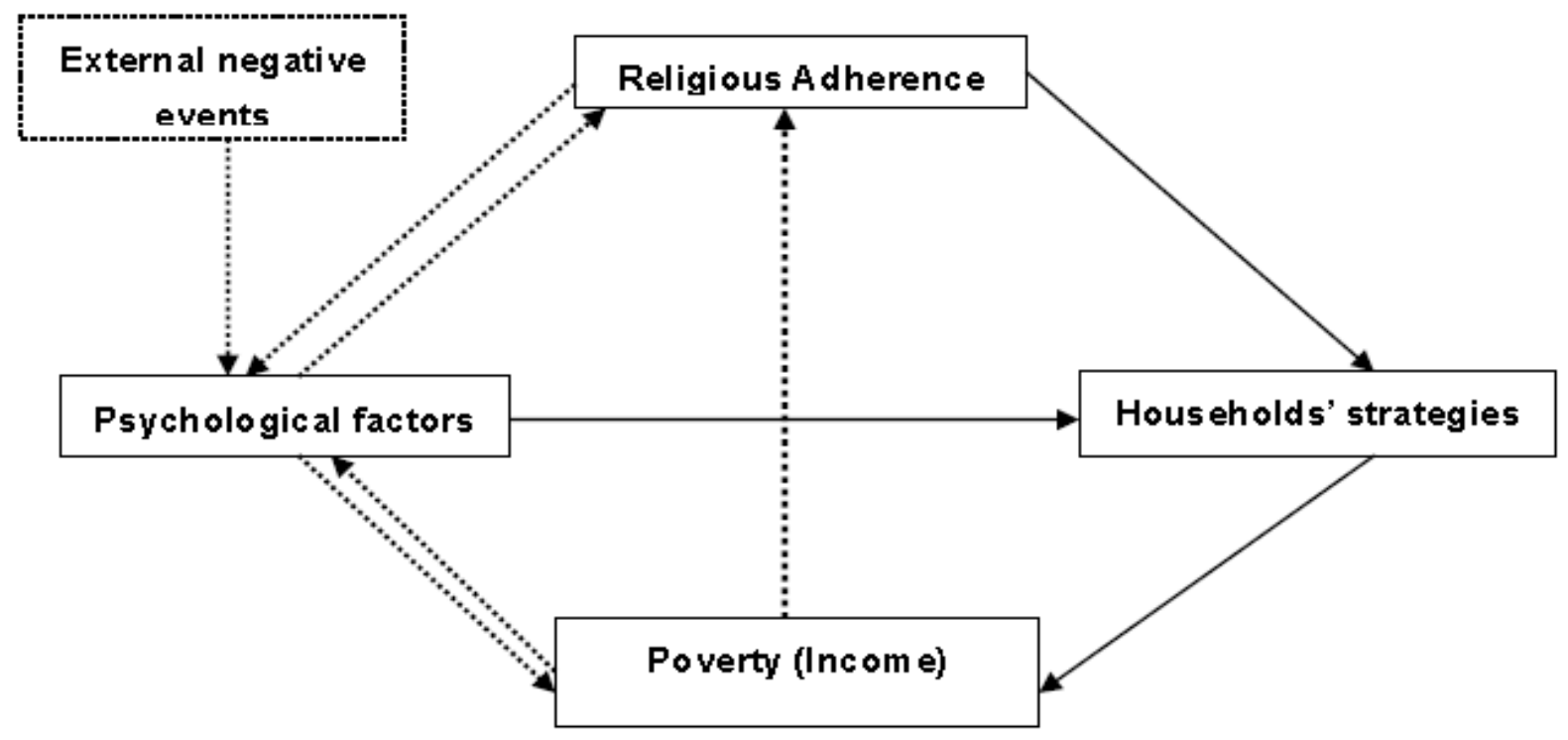

Figure 1. Psychological factors and religious adherence effects of poverty 
Psychological problems such as stress, depression and self-blame do effectively subvert households' coping and risk-management strategies (Garnefski et al., 2005). Strong personality and a person's perception of risk can help to respond well to the hazardous events (Beedell \& Rehman, 1999). Therefore, the ability of making the right decision lies in a person's psychological situation when he or she experiences a stressor. The deterioration of the person's psyche would weaken his ability to follow up on his work, attend programs and activities therefore resulting in a decline of his productivity, production and performance, and as a result decrease his income. As well as material costs of the therapy, this makes the households bear considerable financial burdens and this will lead to higher economic losses. This lead to emergence of more mental disorders and psychological problem that may bring misery and impoverishment. Further deterioration of mental health, and thus, poverty leads to mental disorders and mental disorders in turn lead to further destitution and misery (see Fig. 1).

At the same time, there exists a two way correlation between person's psychological situation and his or her religious adherence. People who suffer from mental disorders may deviate morally and they may lose their faith. Religious adherence, spiritually and believes also are associated with greater mental health, including reduced sociality (Pirutinsky et al., 2011). Studies have found that relationship between religion and mental health had been inseparable in the lives of different groups of people in society (Yeung \& Chan, 2007 and Koenig \& Larson, 2001). Religion was found to be dominant source of happiness, anticipation, trust, wellbeing and comfort (Koenig et al., 1998; Koenig et al., 2004; Park \& Cohen, 1993; Mitchell, 2003).

Religious people are less stressed (Park \& Cohen, 1993) and thus able to find suitable strategies to cope with their uncertainties. Religious practices over the course of hardship improve people's coping capacity against stressors. It also provides direction to help others (Mitchell, 2003). Studies revealed that people who are more religious are more equipped in handling with disastrous situations (Galliard \& Texier, 2010).

Religion, however, can also have negative impact on people's decision making. Studies have documented that there existed a negative relationship between the level of religiosity and people's behaviours. Religion may lead to inappropriate or helpless behaviours in the face of natural hazards (Galliard \& Texier, 2010, p.82). Studies showed that those who are more religious, among Muslims and Christians, have a fatalistic behaviour when they experience hazardous situations (Galliard \& Texier, 2010; Schmuck, 2000) as they believe that these disastrous are only befalling with knowledge of god. Therefore they prefer to refer to their deity to determine their destiny with making no efforts to overcome the stressors.

\section{Data and Research Method}

To investigate the impact of religion and psychological factors on households' income and their risk-management and coping strategies, the present study embraces a quantitative research method. Data were derived with a structured socio-economic questionnaire containing both open and close-ended items. The questionnaire administration was cross-sectional in nature. Pilot test was carried out to test the validity and reliability of the instrument and to ensure that the questionnaire can be understood and accepted by farmers. The pilot study was conducted among 50 farmers in both Kelantan and Terengganu on November 2010. A multistage sampling technique was applied for a representative number of households. The first stage was the selection of two local government states: Terengganu and Kelantan. The reasons for selection was that the two states have been acknowledged to have the highest poverty rate within peninsular Malaysia (EPU, 2011) and are the areas with the most vulnerability and exposure to natural disasters such as flood (Noriyah Ahmad, 2007). The second stage was the selection of three rural districts (strata). The areas selected include: Pasir Putih in Kelantan and Besut and Setiu in Terengganu. In the third stage, households of farmers were then randomly selected and surveyed as representatives of the two states. In order to obtain an accurate data and minimize bias, the questionnaire was distributed to the respondents face to face and in the local language (i.e. Malay), where the researchers explained all the part of the questionnaire to the respondent properly. Between January and February 2011, 400 questionnaires were distributed to the respondents but only 302 were completed in the three communities as follows; 100 questionnaires were received in Pasir Putih, 102 in Besut and 100 in Setiu. Thus, data was analysed using Statistical Package for Social Sciences (SSPS) for windows version 17 program. In order to evaluate the impact of farmers' psychological situation and their religious adherence on their wellbeing, one way ANOVA test was carried. To investigate the relationship between farmers' psychological situation, their religious adherence and their strategies, Pearson correlation coefficients were carried out and calculated.

\section{Measurement of Variables}

To measure the research variables a range of measuring scale and strategies were used. The items were adapted and adopted from previous studies, while some items were developed by the researcher. In this study, the dependent variable is the households' monthly income. The independent variables are households' psychological situation 
and Religious adherence. Households' ability to cope and manage against stressors (strategies) was also used as a dependent variable.

\subsection{Households' Ability to Cope}

Households' ability to cope is measured as the social risk management which are the household implements both pre- and post risks occurrence. The risk prevention and risk mitigation strategies are ex-ante measures which households use or implement to avoid the risk from occurring (risk prevention), or to reduce its impact (risk mitigation). If risk prevention and mitigation (ex-ante) strategies do not work or are ineffective, the household use or implement coping strategies (ex-post) as a tool to cope with the shock once it occurs. For example households were asked to indicate from a given list, the strategies they used and implemented in order to compensate or resolve the decrease or loss of their income and assets.

\subsection{Religious Adherence}

This study involves a measure of religious practice developed by Loewenthal et al (2001) its application is acknowledged among diverse religious groups. The religiosity measurement proposed by this study is of three religious domains (participation, worship, and the learning of religion) regarded as important in the major religious faiths (Loewenthal et al 2001). Therefore the term of religious can be measured as practice by a calculation of visible participation of religious observance, periodical learning of religious texts, and a person's seeming worship regularly. Households were asked to state how often they attend a place of religious worship as well as how often they study religious texts on a five point likert-type scale anchored with (1) never to (5) daily.

\subsection{Households' Psychological Situation}

The households' psychological measured as his attitudinal and behavioural situation when experiencing stressors. Because each person is unique, he/she does not necessarily perceive the same risk in exactly the same way as other (cooper, 2003). Households were asked to answer if the stressors that they had experienced affect on their attitudes and behaviours. Secondly households were asked to answer if the stressors that they had experienced make them sad and discouraged. And lastly households were asked to answer if the stressors that they had experienced make them depressed.

\section{Results}

To evaluate the impact of psychological factors and religious adherence on farmers' monthly income, one way ANOVA test was carried. Using a tukey HSD test, the results in table 1 indicated that most of the selected variables significantly affected households' monthly income. Those who had felt isolated less than one time during a period of six month found to have no different mean in terms of monthly income from those who had felt isolated twice or more. Results showed that farmers who had not felt discouraged during a period of six months had much higher mean monthly income than those who had felt discouraged twice or more. Farmers who never felt discouraged or just felt discouraged only one time had high monthly income by RM226, RM214, and RM185 from those who felt discouraged 2-3 times; 4-5 times and more than 5 times respectively.

Table 1. The effect of farmers' psychological situation and religious adherence on their income

\begin{tabular}{llllll}
\hline Variable & \multirow{2}{*}{ Scale } & & $\begin{array}{l}\text { Mean } \\
\text { Difference }\end{array}$ & $\begin{array}{l}\text { Std. } \\
\text { Error }\end{array}$ & Sig. \\
\hline \multirow{3}{*}{ feeling of isolation } & \multirow{3}{*}{0 to one time } & 2 to three times & $185.690^{* *}$ & 055.590 & .005 \\
& & four to five times & 180.789 & 090.056 & .187 \\
& & more than 5 & 145.000 & 170.332 & .830 \\
feeling & \multirow{2}{*}{0 to one time } & 2 to three times & $226.925^{* *}$ & 055.989 & .000 \\
discouragement & & four to five times & $214.886^{*}$ & 071.557 & .015 \\
& & more than 5 & $185.854^{*}$ & 120.252 & .012 \\
feel of stress & \multirow{2}{*}{0 to one time } & 2 to three times & $251.154^{* *}$ & 063.083 & .000 \\
& & four to five times & $224.279^{* *}$ & 069.382 & .007 \\
feeling depression & \multirow{2}{*}{0 to one time } & more than 5 & $323.427^{* *}$ & 081.916 & .001 \\
& & 2 to three times & $198.384^{* *}$ & 060.397 & .006 \\
& & four to five times & $351.531^{* *}$ & 075.746 & .000 \\
& & more than 5 & $274.791^{* *}$ & 083.388 & .006
\end{tabular}




\begin{tabular}{|c|c|c|c|c|c|}
\hline \multirow{3}{*}{$\begin{array}{l}\text { Involvement } \\
\text { worship }\end{array}$} & \multirow{3}{*}{ Occasionally } & Never & 208.333 & 222.892 & .883 \\
\hline & & Monthly & 141.667 & 270.296 & .985 \\
\hline & & Weakly & $-235.256^{*}$ & 064.198 & .003 \\
\hline \multirow{5}{*}{$\begin{array}{l}\text { Recitation } \\
\text { book }\end{array}$} & \multirow{5}{*}{ Occasionally } & Daily & $-196.212 *$ & 063.127 & .017 \\
\hline & & Never & -217.032 & 220.738 & .863 \\
\hline & & Monthly & $-239.651^{*}$ & 078.440 & .021 \\
\hline & & Weakly & $-131.010^{*}$ & 057.890 & .030 \\
\hline & & Daily & $-161.476^{*}$ & 055.053 & .048 \\
\hline \multirow{2}{*}{$\begin{array}{l}\text { I make no effort to ease } \\
\text { my financial hardship } \\
\text { as I strongly believe it } \\
\text { is just my fate }\end{array}$} & \multirow[b]{2}{*}{ I strongly agree } & I disagree & $-142.54^{*}$ & 039.321 & .041 \\
\hline & & I do not know & 47.638 & 032.004 & .710 \\
\hline
\end{tabular}

Note: $(* *, *)$ indicate the significance at $1 \%$ and $5 \%$ level respectively

Also the results showed that farmers who had never felt stressed or felt stressed only one time have much higher mean monthly income by RM251, RM224, and RM323 than those who felt stressful 2-3 times, 4-5 times and more than five times respectively. People who had never felt depressed or felt depressed only one time have much higher mean monthly income by RM198, RM351, and RM274 than those who felt depressed 2-3 times, 4-5 times and more than five times respectively. Those who have occasionally attended places of worship (Mosques) have lesser mean monthly income by RM235 and RM198 than those attending religious places every day and once a weak. Farmers, however, who occasionally reciting holy books have lesser mean monthly income by RM239, RM131 and RM161than those reciting monthly, weakly and daily respectively. Meanwhile those who they made no effort to ease their financial hardship as they believe that it is just their fate, have less monthly income by RM142 than those who did efforts.

Table 2. The relationship between households' psychological situation, religious adherence and their strategies

\begin{tabular}{lcc}
\hline Variables & Coping strategies & Risk management strategies \\
\hline Number of time you feel isolated & $\mathrm{r}=-0.97^{*}$ & $\mathrm{r}=0.09$ \\
& $\mathrm{p}=0.047$ & $\mathrm{p}=0.438$ \\
Number of time you feel discouraged & $\mathrm{r}=-0.93^{*}$ & $\mathrm{r}=-0.24$ \\
& $\mathrm{p}=0.050$ & $\mathrm{p}=0.338$ \\
Number of time you feel stressful & $\mathrm{r}=-0.138^{* *}$ & $\mathrm{r}=-0.17$ \\
& $\mathrm{p}=0.008$ & $\mathrm{p}=0.385$ \\
Number of time you feel depressed & $\mathrm{r}=-0.106^{*}$ & $\mathrm{r}=-0.019$ \\
& $\mathrm{p}=0.033$ & $\mathrm{p}=0.369$ \\
Attendance places of worship & $\mathrm{r}=-0.180^{* *}$ & $\mathrm{r}=-0.115^{*}$ \\
Recite religious books & $\mathrm{p}=0.001$ & $\mathrm{p}=0.023$ \\
& $\mathrm{r}=-0.246^{* *}$ & $\mathrm{r}=0.038$
\end{tabular}

Note: $r$ denotes Pearson correlation, $(* *, *)$ indicate the significance at $1 \%$ and $5 \%$ level respectively

Table 2 showed the relationship between farmers' psychological situation, their religious adherence and their strategies. Pearson correlation coefficients test indicated that there exists significant negative relationship between farmers' psychological situation and their coping strategies. While there is no relationship found between farmers' psychological situation and their risk management strategies. The more isolated $(\mathrm{r}=-0.97, \mathrm{p}=0.047)$, discouraged $(r=-0.93, p=0.050)$, stressful $(r=-0.138, p=0.008)$, and depressed $(r=-0.106, p=0.033)$ farmers are, the less their coping strategies are.

Also the results confirmed the existence of a significant negative relationship between farmers' level of religiosity and both their coping strategies and risk management strategies. The more farmers attending places of worship $(r=$ 
$-180, p=0.001)$ and the more farmers reciting holy book $(r=-0.246, p=0.000)$ the less their coping strategies. The more farmers attending places of worship $(r=-0.115, p=0.023)$ the less their risk management strategies

Table 3. The relationship between households' psychological situation and their religious adherence

\begin{tabular}{lllll}
\hline Variables & Isolated & Discouraged & Stressed & Depressed \\
\hline Attendance places of worship & $\mathrm{r}=-0.71$ & $\mathrm{r}=-0.14$ & $\mathrm{r}=-0.24^{*}$ & $\mathrm{r}=-0.57^{*}$ \\
& $\mathrm{p}=0.109$ & $\mathrm{p}=0.404$ & $\mathrm{p}=0.040$ & $\mathrm{p}=0.047$ \\
Recite religious books & $\mathrm{r}=-0.105^{*}$ & $\mathrm{r}=-0.99^{*}$ & $\mathrm{r}=0.72$ & $\mathrm{r}=0.19$ \\
& $\mathrm{p}=0.034$ & $\mathrm{p}=0.043$ & $\mathrm{p}=0.105$ & $\mathrm{p}=0.369$ \\
\hline
\end{tabular}

Note: $\left({ }^{*}\right)$ indicate the significance at $5 \%$ level

Table 3 showed the nature of relationship between farmers' religious adherence and their psychological situation. The results confirmed the existence of a significant negative relationship between farmers' level of religiosity and their psychological situation. The more farmers attending places of worship the less stressed $(r=-0.24, p=0.04)$ and the less depressed $(r=-0.57, p=0.047)$ they are. Also the results indicated that the more farmers reciting religious book the less isolated $(r=-0.105, p=0.034)$ and the less discouraged $(r=-0.99, p=0.043)$ they are.

\section{Discussion}

The main findings of the present study were that factors involving some forms of mental problems such as distress, depression and feeling considerably caused decline on farmers' monthly income. Most stresses, depressions and discouragements emerged from climate change such as flooding $(78 \%)$, lack of financial supports (71\%), concern upon viability of food-stuff prices (58\%), and worries from pests and diseases (43\%). Instead of being motivated when experiencing stressors, farmers behaved negatively. These results validate the Cognitive resource theory (Vecchio, 1990) which approved that stress can negatively impact intelligence and decision-making quality. Empirically many studies pointed out that stress negatively affected the quality of decision making (Smith et al., 1997; and Ahituv et al., 1998; Raine, 1999; Manninen et al., 1997) other studies contradict this statement and pointed out that stress also might positively affect people's behaviours and improve their performance (Baumann et al, 2001).

In the studied communities, farmers' mental life was affected by stressors as a result of their irrational manners' development since they became stressful, discouraged and depressed. Manninen et al (1997) stated that psychological distress ${ }^{1}$ predicted overall disability and in particular, disability due cardiovascular diseases, depression, and disorders. Consequently, farmers did not act immediately to minimise the shock or even to solve their problem completely. These findings confirmed as the results appointed the existence of a significant and negative relationship between farmers' psychological situation and their coping strategies. The more farmers are isolated, discouraged, stressed and depressed the less their coping strategies are. In addition studies confirmed that when stress situation is not controllable, cognitive strategies focused on planning and action may not be beneficial or even counterproductive (Garnefski et al., 2005). Other studies demonstrated that the outcomes of prolonged periods of stress, regardless of causes, can lead to depression, which in turn can contribute to a number of other factors, such as increase suicide and alcohol problems (Willock et al, 1999, p.9). The non- existence of any relationship between farmers' psychological situation and their risk management strategies can be explained by the fact that risk management strategies are to be implemented before any uncertainties occur. Therefore, in this case, farmers psychologically feel well and comfortable.

Farmers who attend places of worship and recite holy books were better in generating their income from those attending worship places and reciting holy book infrequently. This is due to the fact that the farmers who are more religious are less stressed, less depressed and less discouraged. This is supported by the results of the significant and negative relationship between the farmers' level of religiosity and their psychological situations mentioned in table 3 . Thus, the present study's findings cited that religion is an influential and vital factor in enhancing people's welfare (Gillard \& Paton, 1999; Schmuck, 2000; Mitchell, 2003). Religion provides direction and strength to help people cope with and manage against uncertainties. At the same time the results indicated that farmers who were more religious implemented less coping and risk management strategies. Religious people might believe that what happened to them was fate (predetermined). As a result they might not respond instantaneously as they leave it to god who determines their destiny (Andreana, 2010; Chester, 2005). One important conclusion we draw is that although religious farmers only employ few strategies, but their monthly income is higher compared to those who seldom practice religious commitments. These findings demonstrate that religious farmers are less stressed, less 
depressed and less discouraged. Therefore, although farmers apply only few strategies in order to minimizes or and mitigate the threats, these strategies were found to be effective and efficient.

\section{Conclusion}

The effect of psychological factors and religious adherence on farmers' income has been investigated. Farmers' psychological situation is an important key in enhancing their strategies. Stresses, depressions and feeling discouraged and isolated are obstacles for the performance and efficiency of farmers' behaviours and decisions. Whereas, even though the results indicated that practicing religious commitments led farmers to implement fewer strategies; they were (religious adherence) crucial in shaping farmers' decision making.

The results of the present study highlights some important implications for policy makers, donors and professionals involved in poverty eradication in Malaysian context. Policy makers, NGOs and international organisations need to work with cluster approach and establish psychosocial- based organisations as well as religious organisations that could contribute to poverty eradication. Organisational psychology offers to bring its expertise to poverty reduction, its ability to assess needs and capacity, develop partnerships with stakeholders, bring about and manage change, and systematically review evaluate, monitor and revise high level mandates, policy development, program implementation and consultation on personal issues (Berry et al., 2009, p.1)

\section{Limitations of the Study}

Respondents were asked to report how many times they felt stressed, isolated, discouraged and depressed during the last 6 months. This study did not heed the severity of the above mental sufferings. Also respondent were given a definition of each of the above variable. Therefore, farmers took the responsibility to determine if they really experience such kind of problems or not. Consequently, this might created bias for the present results.

\section{Acknowledgements}

The authors acknowledge that the present research work was aided with funds from USM Postgraduate Research Grant Scheme (USM-RU-PRGS) Account Number 1001/PSOCIAL/843069. The usual disclaimer applies. Any remaining errors or omissions rest solely with the researchers of this work. The main author acknowledges the financial supports of USM fellowship Scheme.

\section{References}

Abernethy, A. D., Chang, H. T., Seidlitz, L., Evinger, J. S., \& Duberstein, P. R. (2003). Religious coping and depression among spouses of people with lung cancer. Psychosomatics, 43(6), 456-463. http://dx.doi.org/10.1176/appi.psy.43.6.456

Ahituv, N., Igbaria, M., \& Sella, A. (1998). The effects of time pressure and completeness of information on decision Making. Journal of Management Information System, 15(2), 153-172.

Andreana, R. (2010). Acts of God(s): the role of religion in disaster risk perception. Humanitarian practice network, (48). Retrieved December 30, 2010, from http://www.odihpn.org

Baumann et al. (2001). Commitment and care: The benefits of a healthy workplace for nurses, their patients and the system. Ottawa, Ontario, Canada: Canadian Health Services Research Foundation.

Beedell J. D. C., \& Rehman, T. (1999). Explaining farmers' conservation behaviour: why do farmers behave the way they do? Journal of environmental management, 57, 165-176. http://dx.doi.org/10.1006/jema.1999.0296

Berry, H. L., Hogan, A., Owen, J., Rickwood D., \& Fragar, L. (2011). Climate Change and Farmers' Mental Health: Risks and Responses. Asia Pacific Journal of Public Health, 23(2), 119S-132S. http://dx.doi.org/10.1177/1010539510392556

Berry, M. O., Reichman, W., Klobas, J., MacLachlan, M., Hui, H. C., \& Carr, S. C. (2009). Humanitarian work psychology: The contributions of organizational psychology to poverty reduction. Journal of Economic Psychology. http://dx.doi.org/10.1016/j.joep.2009.10.009

Booth, N. J., \& Lloyd, K. (2000) Stress in farmers. The International Journal of Social Psychiatry, 46(1), 67-73. http://dx.doi.org/10.1177/002076400004600108

Carr, S. C., Maclachlan, M., Reichman, W., Klobas, J., Berry, M. O., \& Furnham, A. A. (2008). Organizational Psychology and poverty reduction: where supply meets demand. Journal of Organizational Behavior, 29, 843-851. http://dx.doi.org/10.1002/job.548

Centre for Rural Mental Health CRMH. (2005). Depression in Farmers and Farming Families. Project Report 
June, 2005.

Chaudhuri, S. (2003). Assessing Vulnerability to Poverty: Concepts, Empirical Methods and Illustrative Examples, Working Paper. Columbia University.

Chester, D. K. (2005). Theology and disaster studies: the need for dialogue. Journal of volcanology and geothermal research, 146(4), 319-328. http://dx.doi.org/10.1016/j.jvolgeores.2005.03.004

Chester, D. K., Duncan, A. M., \& Dibben, C. J. L. (2008). The importance of religion in shaping volcanic risk perception in Italy, with special reference to Vesuvius and Etna. Journal of Volcanology and Geothermal Research, 172, 216-228. http://dx.doi.org/10.1016/j.jvolgeores.2007.12.009

Cooper, D. (2003). Psychology, risk and safety: understanding how personality and perception can influence risk taking. Professional safety. Journal of the American society and safety engineers (ASSE), 39-46

Crawford, P. (1998). Spiritual issues and recovery management. Australian journal of emergency management, 13(2), 32-34.

Economic Planning Unit EPU. (2011). Incidence of Poverty by Ethnicity, Strata and State, Malaysia, 1970-2009. Retrieved April 12, 2011, from http:/www.epu.gov.my/household-income-poverty

Edwards-Jones, G., Deary, T., \& Willock, J. (1998). Incorporating psychological variables in models of farmer behaviour: does it make for better predictions. Etud Rech Syst Agraires Dev, 31, 153-173.

Eisner, C. S., Neal, R. D., \& Scaife, B. (1998). Depression and anxiety in farmers. Prim Care Psychiatry, 4, $101-105$.

Ellis, F. (2000). Rural Livelihoods and Diversity in Developing Countries. Oxford University Press, Oxford.

Ensor, M. O. (2003). Disaster evangelism: religion as a catalyst for change in post-Mitch Honduras. International journal of mass emergencies and disasters, 21(2), 31-49.

Eriksen, S., \& Silva, J. A. (2009). The vulnerability context of a savanna area in Mozambique: household drought coping strategies and responses to economic change. Environmental science \& policy, 12, 33-52. http://dx.doi.org/10.1016/j.envsci.2008.10.007

Ersado, L. (2006). Rural Vulnerability in Serbia. World Bank Policy Research. Working Paper No 4010.

Gaillard, J. C., \& Texier, P. (2010). Religions, natural hazards, and disasters: An introduction. Religion, 40, 81-84. http://dx.doi.org/10.1016/j.religion.2009.12.001

Garnefski, N., Baan, N., \& Kraaij, V. (2005). Psychological distress and cognitive emotion regulation strategies among farmers who fell victim to the foot-and-mouth crisis. Personality and indivudial differences, 38, 1317-1327.

Gillard, M., \& Paton, D. (1999). Disaster stress following a hurricane: the role of religious differences in the Fijian islands. The Australian journal of disaster and trauma studies, 2. Retrieved December 17, 2010, from, http:/www.massey.ac.nz/ trauma/issues/1999-2/gillard.htm

Gorgievski, M. J., Bakker, A. B., Schaufeli, W. B., Van der Veen, H. B., \& Giesen, C. W. M. (2010). Financial problems and psychological distress: Investigating reciprocal effects among business owners. Journal of Occupational and Organizational Psychology, 83, 513-530. http://dx.doi.org/10.1348/096317909X434032

Goudge, J., Gumede, T., Gilson, L., Russell, S., Tollman, S. M., \& Mills, A. (2007). Coping with the cost burdens of illness: Combining qualitative and quantitative methods in longitudinal, household research. Scandinavian Journal of Public Health, 35, 181-185. http://dx.doi.org/10.1080/14034950701355551

Hinton R., \& Earnest J. (2010). Stressors, coping and social support among women in Papua New Guinea. Qualitative Health Research, 20(2), 224-238. http://dx.doi.org/10.1177/1049732309357572

Kahn, R. S., Wise, P. H., Kennedy, B. P., \& Kawachi, I. (2000). State income inequality, household income, and maternal mental and physical health: cross-sectional national survey. BMJ, 32, 1311-1315. http://dx.doi.org/10.1136/bmj.321.7272.1311

Kamur, S., \& Routray, J. K. (2009). Flood proneness and coping strategies: the experiences of two villages in Bangladesh. Journal of Overseas Development Institute.

Koenig, H. G., \& Larson, D. B. (2001). Religion and mental health: Evidence for an association. International Review of Psychiatry, 13, 67-79. http://dx.doi.org/10.1080/09540260124661

Koenig, H. G., George, L. K., \& Peterson, B. L. (1998). Religiosity and remission of depression in medically ill older patients. American Journal of Psychiatry, 155, 536-542.

Koenig, H. G. (2007). Case discussion: religion and coping with natural disaster. Special edition: spirituality/medicine interface project. Southern medical association, 954. 
Koenig, H. G.., George, L. K., \& Titus, P. (2004). Religion, spirituality, and health in medically ill hospitalized older patients. Journal of the American Geriatrics Society, 52(4), 554-562.

Levin, J. S. (1994). Religion in aging and health: theoretical foundations and methodological frontiers. Thousand Oaks, Calif, Sage Publications.

Loewenthal, K. M., Macleod, A. K., \& Cinnirella, M. (2001). Are Women More Religious Than Men? Gender Differences in Religious Activity among Different Religious Groups in the UK. Personality and Individual Differences, 32, 133-139. http://dx.doi.org/10.1016/S0191-8869(01)00011-3

Manninen, P., Heliovaara, M., Riihimaki, H., \& Makela, P. (1997). Does psychological distress predict disability? International journal of epidemiology, 26(5), 1063-1070. Retrieved December 12, 2011, from http://ije.oxfordjournals.org/content/26/5/1063.full.pdf

McCubbin, H., \& Figley, C. (1983). Stress and the family: Coping with catastrophe. New York: Brunner/Mazel

Mitchell, J. T. (2003). Prayer in disaster: case study of Christian clergy. Natural hazards review, 4(1), 20-26. http://dx.doi.org/10.1061/(ASCE)1527-6988(2003)4:1(20)

Mohanthy, A. K., \& Misra, G.. (2000). Psychology of poverty and disadvantages. Advance in Psychological Research in India, Series 2.

Noriyah Ahmad. (2007). Over View of Poverty Eradication in Malaysia. Economic Planning Unit, Malaysia

Page, A. N., \& Fragar, L. R. (2002). Suicide in Australian farming, 1988-1997. Australian \& New Zealand Journal of Psychiatry, 36, 81-85.

Park, C. L., \& Cohen, L. H. (1993). Religious and nonreligious coping with the death of a friend. Cognitive Therapy and Research, 17, 561-577. http://dx.doi.org/10.1007/BF01176079

Patel, V., \& Kleinman, A. (2003). Poverty and common mental disorders in developing countries. Bulletin of world health organization, 81, 609-615.

Pirutinsky, S., Rosmarin, D. H., Pargament, K. I., \& Midlarsky, E. (2011). Does negative religious coping accompany, precede, or follow depression among Orthodox Jews? Journal of Affective Disorders. http://dx.doi.org/10.1016/j.jad.2011.03.015

Prowse, M. (2003). Towards a Clear Understanding of Vulnerability in Relation to Chronic Poverty. Chronic Poverty Research Centre. CPRC Working Paper No24

Riskind, J. H. (1999). The psychology of looming vulnerability: Its relationships to loss. Journal of Loss and Trauma, 4(1), 25-45.

Schmuck, H. (2000). An act of Allah: religious explanations for floods in Bangladesh as survival strategy. International journal of mass emergencies and disasters, 18(1), 85-95.

Smith, C. A. P, Arnold, V., \& Sutton, S. G. (1997, July). The impact of time pressure on decision making for choice and judgment tasks: Implications for audit planning. Accounting and Business Review, 365-383.

Vecchio, R. (1990). Theoretical and empirical examination of cognitive resource theory. Journal of Applied Psychology, 75(2), 141-147. http://dx.doi.org/10.1037/0021-9010.75.2.141

Wamsler, S. (2007). Bridging the gaps: stakeholder-based strategies for risk reduction and financing for the urban poor. Journal of Environment and Urbanization, 19, 115-142. http://dx.doi.org/10.1177/0956247807077029

Yeung, W. J., \& Chan Y. (2007). The positive effects of religiousness on mental health in physically vulnerable populations: A review on recent empirical studies and related theories. International Journal of Psychosocial Rehabilitation, 11(2), 37-52.

\section{Notes}

Note 1. Ex-Post coping strategies are methods implemented by households to survive after experiencing unfavoured events that lead to livelihood failure (Prowse, 2003). These types of strategies are implemented after the shock occurred. Ex-ante risk management strategies are methods used by households to prevent or minimize the impact of negative events. They are forward planning strategies in nature where households spread risk across a diverse set of activities (Ellis, 2000). These types of strategies are implemented before the shock occurs. Ex-ante strategies can be categorised in two set: risk-mitigation strategies and risk-reduction strategies.

Note 2. Psychological distress considered as a measure of mental overstrain or mild mental symptoms reflecting a general feeling of not being well (Manninen et al., 1997, P.1067). 